\title{
THE EFFECT OF INTEGRATED SOCIAL STUDIES TEACHING-LEARNING TOWARD THE ENHANCEMENT OF STUDENTS' CRITICAL AND MEANINGFUL THINKING SKILLS
}

\author{
Yuyun Kurniasari ${ }^{1}$
}

\begin{abstract}
This research background was the application of less optimal Social Sudies Learning Process in schools in enhancing students' critical and meaningful thinking skills and at the Social studies learning which were still taught separately based on appropriate field of studies such as Geography, Sociology, History and Economics. This research aimed to find out the effect of integrated Social studies Learning towards the students' critical and meaningful thinking skills enhancement. The research method applied in this study was quasi experimental research using Nonequivalent Control Group Design. One class was chosen as an experimental class with Integrated Social studies Learning and one control class was choosen with separated Social studies learning. The data technique collection used was in the form of test result which was supported by observation and questionnaire. The analysis technique of test data to examine the research hypothesis applied SPSS version 16 with the analysis tools: normality test, homogeneity test, parametric analysis with $t$ test and gain. The test findings showed that the learning of Integrated Social studies affected by the students' critical and meaningful thinking skills enhancement. The learning of this Integrated Social Science was recommended as a learning alternative which was able to enhance students' critical and meaningful thinking skills
\end{abstract} studies learning

Key words: Cultural Value Inheritance, Indeginous Scoiety, History Learning, social

\section{Introduction}

Social studies is the integration of various branches of social science such as: Sociology, History, Geography, Economics, Politics, Law, and Culture. Wesley (in Zevin, 2007: 5) has stated that "the social studies are the social sciences simplified for pedagogical purposes". The Definition shows that social studies are the cores which form the essence of Social studies subjects. The basic competency of Social studies in Junior High School Level (SMP) comprises study materials of: sociology, history, geography, and economics.

The Rule of the Ministry of National Education (MONE) of Republic of indonesia (Permendiknas RI) 22 in 2006 (Sapriya, 2012: 201) has published that Social studies of Junior High School aims to make the students have the following skills: (a) to

\footnotetext{
${ }^{1}$ Yuyun Kurniasari, History Teacher in Junior High School (SMP) in Cibeubeur, Cianjur. For academic interest, the author can be contacted through the email address: yuyunkurniasih@gmail.com.
} 
understand the concepts related to social life and their environment; (b) to possess basic skills think logically and critically, cognitive curiosity, and inquiry to solve problems, as well as skills in social life; (c) to possess commitment and awareness toward social and humanity values; and (d) to possess skills in communicating, cooperating, and competing in plural societies whether in local, national or global levels.

In the effort to realize the goals of Social studies Education above; it is therefore required students' critical thinking skills. The implications of education in the learning process an approach able to support the students to develop their thinking capability should be applied. Al Muchtar (2013) has emphasized that thinking skills are skill processes which can be trained through creating condusive learning atmosphere that could stimulate the students to enhance thinking skills.

Teachers as spearheads of education are required to be able to give chances to the students to think, in order to help the students active in building their knowledge themselves. Abdulkarim (2008) has stated that "... while planning a learning or while learning process is in progress, the teachers must invite and condition the students to think" so that the students can optimize their thinking skills. The increasing amount of learning requires the students to be active in learning activities, not only to achieve or to listen, but also to enhance students' critical thinking skill to be improved by themselves, so the tendency of students to be passive during the learning process, identified by passively achieving any information they get while studying, can be avoided.

In Parallel to this, Wiriaatmadja (2002: 307-308) has also stated that the process of teaching learning of social studiess will be tough if it is done more actively. From that idea, it can be concluded that Social studies learning which supports the students to study actively will not only facilitate the students to be able to optimize their thinking capability, but also build the meaningfulness of studying to the students themselves in order to improve their social comprehension. Learning will be more meaningful if the students directly experience what they are studying by activating all the senses than only listening the teachers explanation. So, any information about events, facts, and concepts generalization in social studies education are not taken from the teacher but as the result of their learning activities. The meaningfulness of learning as a result of teaching learning process is marked by the occurrence of relationships among between aspects, concepts, information or new situation that relevant to the components structure of the students' cognitive.

In practice, it shows that there are some problems in Social studies learning at schools nowadays. The research finding of Somantri (2001:39) showed the indication and conclusion that social studies learning at school lately is less supportive towards the enhancement of students' critical thinking. Social studies learning is lack of support to the students' critical thinking skills because in the process of learning the students only "take it for granted". Most of the process of learning still aims to make the incapable students become capable. The new implemented learning is aimed at reaching the process of conveying, giving, transferring knowledge from the teacher to the students.

Another obstacle which is experienced in learning social studies is that the learning is still less meaningful because social studies is considered as a "rote subject" so it that makes the students passive and get bored. Ausubel 
(1961:501) has contended that the students must be able to develop students' cognitive potency through the process of meaningful learning process.

Ahmadi (2011:1) has stated that "the process of learning is not just to memorize merely concepts or facts, but it is more than that, it is an internalization activity of inter-concepts in order to generate a full understanding", so that the concepts which are learned will be fully comprehended and uneasily forgotten.

In line with this, Yani (2010: 9) has stated that "learning through memorizing is not interesting, it will be easily-forgotten and meaningless to the students". According to Yani, new information accepted by the students can be considered meaningless because it is not related to the knowledge which is known by the students previously.

The learning of social studies still has another drawbacks. The implementation of Social studies learning in SMP/MTs is still largely used separately based on each respective fields of study including sociology, history, geography and economics. It will surely hinder the achievement of the goal of Social studies itself which is formulated on the basis of social reality and phenomena which needs interdisciplinary approach from aspects and branches of social studies.

Integrated learning is a model of curriculum implementation which is recommended to be applied in all education levels, started from Secondary Schools (SD/ MI) to Senior High Schools. Integrated learning is essentially a learning approach which enables students, individually or collectively, to be active in looking for digging, and finding concepts as well principle holistically and authentically. (Depdikbud, 2013:12).
Throughintegratedlearning, thestudents can acquire direct experience, and therefore the students can enrich their strength to accept, keep, and produce impressions about things she or he learns. Thus, the learners are skilled to find by themselves various concepts which they learn holistically, meaningfully, authentically, and actively. The way of learning experience packaging which the students design impacts to the meaningfulness of the experience of the students.

Based on the writer's experience during being on duty at SMP Negeri 4 Cianjur, Social studies teaching and learning is still implemented separately according to the respective fields of study comprising geography, sociology, history, and economics; whereas in Junior High School, Social studies subjects are taught through interdisciplinary approach. This, of course, affects to the students' paradigm which only views one obstacle from one side only. Expository approach in the process of Social studies learning is still implemented. Social studies learning at school still implements memorizing technique (rote learning), so that learning becomes uninteresting, easily forgotten and meaningless to the students.

The students only take for granted whatever the teachers convey while teaching learning process takes place. Students' participation in the learning process is passive. This is possibly because the material presented is not quite interesting, or the capability of students to think critically is absolutely limited.

This cannot be allowed. Teachers are required to be able to innovate their learning process so that, at the end, the goal, the meaningful learning process could be achieved. On the other hand, students' 
capability in thinking critically is also needed to be improved optimally in the learning process.

By observing the problems experienced in Social studies learning and the existence of assumption that Integrated Social studies learning is potential to be developed, Integrated Social studies learning will thus be chosen as a solution to the problem of Social studies learning. The researcher is interested in carrying out a research about The Effect of Integrated Learning Social studies towards the Enhancement of Students' Critical and Meaningful Thinking Skills (Quasi Experimental Research in Junior High School 4, Cianjur).

\section{Problem Identification Formulation}

and

The problems of social studies learning mentioned above do not occur because of various cause. There are many factors causing problems of learning which are less supportive towards the enhancement of students' critical and meaningful thinking capability. As having been stated in the problem preface above that the main problems are lied on teachers and students factors in the learning process.

The problem which becomes the primary focus in this study is the effect of Integrated social studies learning towards the enhancement of students' critical and meaningful thinking skills in junior high school. Specifically, this researchwouldassess the effect of integrated social studies learning towards the enhancement of students' critical thinking skill, the effect of integrated social studies learning towards the enhancement of students' meaningful thinking skill and the effect of Integrated social studies learning towards the enhancement of students' critical and meaningful thinking skills to the students of Junior High School level.
Based on the illustration described in problem identification, the research problems can thus be formulated as follow:

1. Is there any significant effect of Integrated Social studies learning towards the enhancement of students' critical thinking skill?

2. Is there any significant effect of Integrated Social studies learning towards the enhancement of students' meaningful learning skill?

3. Is there any significant effect of Integrated Social studies learning towards the enhancement of students' critical and meaningful thinking skills?

\section{The Objectives of the Study}

The study is generally aimed at obtaining the illustration about the enhancement of students' critical and meaningful thinking competency on Integrated Social studies learning. In particular, the objectives of this research are:

1. To analyze the effect of Integrated Social studies teaching and learning towards the enhancement of students' critical thinking skill.

2. To analyze the effect of Integrated Social studies teaching and learning towards the enhancement of students' meaningful thinking skill.

3. To analyze the effect of Integrated Social studies teaching and learning towards the enhancement of students' critical and meaningful thinking skills.

\section{The Significance or the Benefits of the Study}

The research findings are expected to give students some benefits, such as followings: 
1. The Theoretical Benefit

It benefits the students through contributing some thoughts in order to enhance social studies learning. The research findings are expected to be studied and the discussion about the enhancement of integrated social studies learning in order to improve students' ability in thinking critically and meaningfully. Recently, Social studies Education is confronted to the challenges to contribute in enhancing capability and potency optimization of thinking.

2. The Practical Benefit

The results of this research are expected:

a. to give contribution of intellectualization in the optimization of Social studies teachers' competency improvement in implementing the learning process, especially those correlated to the implementation of Integrated Social studies. It is also expected to be beneficial to other further researchers in carrying out similar research.

b. to give the students new experience through the implementation of integrated approach in Social studies learning, so that the learning process becomes meaningful, and it is expected to be able to grow students' skills in problem solving, cooperative, and communicating skill which can train and stimulate students to enhance their reasoning cognitive critically.

\section{Review of Related Literature Critical Thinking}

The definition of critical thinking has been experiencing growth along with the increasing of ability constituent elements to think critically. The development of the definition of critical thinking can be comprehended from a number of definitions which are formulated below:
John Dewey (Fisher, 2008:2) has used the term of "reflective thinking" and defined it as "... consideration which is active, persistent and conscientious about a conviction or a cognition which is taken for granted, which is viewed from the supportive reasonable points and further conclusions which becomes its tendency.

Robert Ennis (1992) has added the component of the purpose of critical thinking in widely used definition; "reasonable reflective thinking focused on deciding what to believe or do". According to Ennis's view, critical thinking is a reasonable and reflective thinking concerned to decide what to believe or to do."

The definition of critical thinking developed by Ennis tends to emphasize how somebodymakes decisions or considerations. Furthermore, Ennis (Sapriya, 2012:144) has made identification of five key elements to critical thinking: practical, reflective, rational, trustable, and applicable. With the underlying of this thought, Ennis formulates the definition of critical thinking as an activity to think reflectively and rationally which focus on determining what to convince and to do.

In responding to Ennis (Rante, 2008) there are twelve indicators of critical thinking that are classified into five thinking skills: (1) Giving simple questions, consisting of a) focusing on questions; b) analyzing arguments; c) asking and answering questions about an explanation and challenge; (2) Basic skills building, consisting of: a) examining the credibility of one source; b) observing and to considering observations findings; (3) inference, consisting of: a) making deduction and considering the deduction results; b) making induction and considering the induction results ;c) making 
and considering the value of a decision; (4) Making further explanation, consisting of: a) defining terms; b) identifying assumption; and (5) Strategy and tactics, consisting of: a) deciding an action; and b)interacting with others.

The necessity to enhance critical thinking skill at school is admitted by some education experts. There are several reasons which become the consideration why critical thinking skill is something important in modern education. Tilaar (2011:17) has stated that enhancing critical thinking in education will fully give chances to students' personal development because they feel that they are given chances and feel that their rights are respected in their personal development. Arraying students into life maturity doesn't mean that they are given something readily prepared, but it is more about engaging them in the fulfillment of their own self-development and the array of the development itself. Finally, the enhancement of critical thinking is absolutely required in democratic life because democracy can solely be developed if the citizens are able to think critically in every political, social and economic problems

\section{Meaningful Learning}

Ausubel, Novak, and Hanesian (in Suparno, 1997: 54) stated that there are two kinds of learning: (1) meaningful learning and (2) rote learning. Meaningful learning can be achieved when the learners are able to correlate the information to the concepts they have just got (known as subsumers) which is relevant into the cognitive structure of the learners themselves. However, if the learners try to memorize the information they have just got without correlating it to the concepts having existed in cognitive structure, this condition will be called as a rote learning. A learning process will be more easily learned and comprehended by the students if the teachers are able to make the students understand as easily as possible so that the students can correlate their new knowledge with the knowledge they have previously had. It is, therefore, the core of meaningful learning which was initiated by Ausubel (Yani, 2010: 39).

According to Ausubel (Yani, 2010: 3940), meaningful learning consists of four stages:

1. Derivative subsumption, a process trying to elaborate general concepts into smaller parts.

2. Correlative subsumption, an accommodation process towards new concept the students learn.

3. Super-ordinate learning, a high level learning. In this concept, the students find new concepts/material by the students themselves through the identification and inquiry process.

4. Combinatorial learning, an analogically learning process.

Jonassen (2011) mentioned some characteristics of meaningful learning, they are (1) active (manipulative/observant); (2) constructive (articulate/reflective); (3) intentional (goal-directed/regulatory); (4) authentic (complex/contextual); and (5) cooperative (collaborative/conversational)

Active means that in the meaningful learning, the learners are active to observe their environment and to observe the effect of human's behavior towards their environment. Constructive means that the student be able to build his or her knowledge himself/herself, to be able to do some reflection towards the activities 
which he or she does as an meaningful learning experience. Intentional refers to the definition that learning must be purposed and designed well, so that the students can articulate them themselves towards the goals they are going to achieve. Authentic means that the concepts they are learning must be meaningful and factual. The learning will be meaningful if it is correlated with real life. Cooperative means that meaningful learning requires a communication and experience exchange with their learning club.

Dahar (2011: 99) has supported two requirements to the meaningful learning: (1) the material which is going to be learnt must bepotentiallymeaningful, and(2)thelearners should have a goal of meaningful learning. Potential meaningfulness of subject matter depends on two factors; (1) the material has own logical meaningfulness, and (2) relevant ideas must be found in students' cognitive structure. A material which provides logical meaningfulness is a material that is similar with what the students already know and a material which can be stated in various ways without changing the meaning.

The measurers that have lead to the emersion of meaningful learning, according Koswara (2011) are as follows: (1) teaching orientation is merely directed to academic accomplishment facet, it is also aimed at enhancing learning attitude and interest as well as basic potency of the students; (2) the topics chosen and learned must be built upon students' relevant experience.; (3) the teaching method applied must make the students involved in a direct and fun activity; (4) in the learning process it is required to be prioritized the students' chance to play and corporate with others; (5) the materials used should be concrete; and (6) in assessing the students, the teacher not only emphasizes students' cognitive through written test, but also include all the domains of students' relevant attitude by implicating a number of assessment tools

The teachers should always try to find out and to dig concepts which are owned by the students and help them combine them harmoniously with new knowledge has been taught. The teacher are also required to have capability to make lesson plans which enable students to learn actively not just for memorization, but to support the students to comprehend what they have learnt by correlating new knowledge with what the students have in advance. This is like what National Councilfor the Social Studies (1994: 169) has stated that "...Students develop new understanding through a process of active construction. They do not passively receive or copy curriculum content; rather, they actively process it by relating it to what they already know (or think they know) about the topic".

\section{The Definition of Social Studies Education}

Social studies is derived from U.S education. The original name of IPS in United States is "Social Studies". Social science Education Council (SSEC) stated Social studies as "Social studies Education", while National Council for Social Studies (NCSS), has stated that the term of Social science as "Social Studies" term. NCSS has defined Social studies as follow:

Social studies are the integrated study of the social sciences and humanities to promote civic competence. Within the school program, social studies provides 
coordinated, systematic study drawing upon such disciplines as anthropology, archeology, economics, geography, history, law, philosophy, political science, psychology, religion, and sociology, as well as appropriate content from the humanities, mathematics, and natural sciences (1994:3).

The definition above shows that Social studies is an integrated study from social and humanities sciences to develop the value of citizenship. CitizenshipEducation meansthat the students must be prepared to participate effectively in dynamics of community life. The students have awareness to improve their achievement as a form of responsibility of faithful citizens to their nation. Education values in this goal are more emphasized in citizenship. The material presented should conform to the circumstance, for example when talking about school environment; the students are thus required to study well. They are the generations who will substitute the recent generations.

Communication Forum II HISPIPSI in Yogyakarta (1991) has formulated social studies education as a simplification or adaption of disciplines of social and humanities sciences as well as human's basic activities which are organized and presented scientifically and pedagogically/ psychologically to the education goals (Somantri, 2001:92). The definition is similar to the formulation developed by Wesley who has argued that Social studies Education in curriculum of elementary and high school as "...the social sciences simplified for pedagogical purposes” (Zevin, 2007: 5).

The primary purpose of Social studies is "...to help students develop the ability to make rational decisions so that they can resolve personal problems, and through social action, influence public policy" (Banks, 1977: 31). The purpose of Social studies which was proposed by Banks is fundamentally to improve students' potency so that they have sensitivity to social problems, to possess positive mentality towards the restoration of each imbalance, and to be skillful in solving every problem which happens in daily life whether it happens to themselves as well as to the society.

\section{The Concepts of the Integrated Social studies Learning}

Social studies subjects in Junior High School level,as contained in Training Modul ofCurriculum Implementationin 2013, Social studies in Junior High School (Ministry of Education and Culture/Kemdikbud, 2013) has covered study materials of "Geography, Economics, History, and Sociology", which are learnt integratedly, as said by Sapriya (2009).

In integrated learning approach, the learning process is managed from various schools of social studiess. The development of integrated learning, in this case, can take one topic from a certain branch of sciences which then completed, discussed, expanded and deepened with various other sciences disciplinary.

NCSS (1994:165) has more detailed stated that the integration in Social studies learning consists of: (1) integrative in its treatment of topics; (2) integrative across time and space; (3) integrates knowledge, skills, beliefs, values, and attitudes to action; (4) include effective use of technology; and (5) integrates across the curriculum.

1. Integratied in its treatment of topics.

Integratied in imposing a topic means that in Social studies learning, a topic can be taken from every certain disciplines 
completed by ideas taken from art, science and humanities from recent events and the experience of the students themselves. The topics dicussed traverse the boundaries of social studies disciplines.

\section{Integraties across time and space.}

The social studies learning can be developed integratively through time and space, relates past experience to the future time. Such kind of learning process will help thestudents appreciate their local community recently and also in other cultures.

3. Integrated knowledge, skills, beliefs, values, and attitudes to action.

Social studies learning integrate knowledge, skills, beliefs, values, andattitudes to act. During the learning progress, the five aspects are integrated in one process.

\section{Includes effective use of technology.}

Integrated Social Sciemce learning includes in effective use of technology which is able to enrich important dimension of students' learning. The teachers can give more information to the students through movies, videos, and other electronic media. The teachers can lead the students to use computer to write, to edit or to report research findings. Computer based learning will enable the students to search larger information sources.

\section{Integrates across the curriculum.}

Eventually, the strenght of Social studies learning is integreated across the curriculum. It can give the students chance to read and learn the material, to appreciate art and literature, to communicate in spoken and written, to conduct some researches, and to apply their knowledge and skills which are taught in all school subjects.

There are some integrate models in Social studies learning (Depdiknas, 2006) as mentioned below:

\section{a. Integration Models Based on Topics}

In learning social studies, the integration can be applied based on the related topic, for example "Citizens' economic activities". The citizens' economic activities topic can be viewed from various disciplines which are scoped in Social studies. The citizens' economic activities in this case are reviewed from the spread and the condition of physical geography which is included in Geography disciplinary. Sociologically, the citizens' economicactivitiescanaffectsocialinteraction in society and vice versa. Historically, time by time, the citizens' economic activities face some changes. Furthermore, the concept mastery about kinds of economic activities to the level of growing the creativity and independence in conducting economic action can be improved through some competency correlated to Economics.

b. Integration Model Based on Primary Potency

The integration of Social studies can be enhanced through some topics based on primary potency in local region; for instance, "Bali Potencies as Tourism Destination". In learning Bali Culture, it can be studied and viewed from its nature factors, chronological history and causalities as well as the society's attitude towards the rules. Through the study of primary potency existing in their area, the learners can understand their region condition, they can also comprehend Basic Competency involved in some disciplines incorporated in Social studies.

c. Integration Model Based on Problems

Integrated model in other social studiess is based on existing problem, for example "Indonesian Labors". In integrated learning, Indonesian Labor can be viewed from some affected social factors, i.e. factors of geography, economy, sociology, and history. 
The Characteristics of Social Studies Education Materials

The characteristics of Social studies subjects in SMP/MTs (Kemdikbud, 2013: 10) are as follows;

1. Social studies is the element combinations of Geography, History, Economics, Law and Politics, Citizenship, sociology, and even fields of humanities, education and religion.

2. The Gist of Competency and Basic Competency of Social Science come from the scholarly structure of geography, history, economy and sociology which are packaged as good as possible to be a certain subject matter or topic (theme).

3. The Gist of Competency and Basic Competency of Social studies are also related to various social problems which are formulated through interdisciplinary and multidisciplinary.

4. The Gist Competency and Basic Competency can be correlated to the events and the changes of society life through the principle of cause-effect, regional, environment adaptation and management, structure, process and social problems as well as life struggle in order to survive, such as the fulfillment of necessity, authority, justice and security.

5. The Gist of Competency and Basic Competency of Social studies use three dimensions (space, time, and value/ moral) in studying and understanding social phenomena as well as human life as a whole.

Based on the characteristics above, in the integrated learning process the students become the primary consideration and as far as possible it is sought to give them direct experience of the material learn. Some disciplines are found, and it means that one problem can be studied from some points of view. It means that the learning process doesn't go with subject matter in one discipline. Learning production will develop itself according to the students' need and interest because learning process is suitably based on students' characteristics.

\section{Integrated Social Studies Teaching and Learning in Enhancing Students' Critical Thinking and Meaningful Learning Skills}

Learning is a process of thinking. Sanjaya (2008: 219) has stated that "Learn to think is emphasized to the process of looking for and finding knowledge through individual interaction with his environemnt." It means that learning to think in education process at school is not just emphasized to the accumulation of subject knowledge, but, it prioritized students' ability to achieve their knowledge. According to Battencourt (in Sanjaya, 2008: 219), Learning process in thinking learning is" to participate with the students to form knowledge, to create a meaning, to find out the enlightenment, to act critically and to justify".

National Council for The Social Studies (1994:160) has stated that"...Teacher should not only expose their students to curriculum content but should also provide them with opportunities to think and communicate in ways that will help students construct a working knowledge of such content". The statement above conveyed by NCSS shows that in the learning process, the teachers are required to be capable of giving the students chance to think how they build their own knowledge. 
According to Sapriya (2009: 12) Integrated Social studies learning at schools (Junior High School) fundamentaly aims at making "this subject more meaningful to the students so that material learning organization is suited to the students' environment, characteristic, and necessity". Therefore, the students are able to master dimension of social studies learning at school: "to master knowledge, skills, attitudes, values, and action" (Sapriya, 2009).

Kemdikbud (2013) has stated that inegrated learning is fundamentally a ;earning approach which enables the students individually and collectively to be active in searching, digging, and finding the concepts and principles holistically and autentically. Through integrated learning the students are able to enrich their power to achieve, to keep and to produce impressions about what they have learn.

The learning process of Integrated Social studies, as mentioned above, enables the students to be skillful in finding by themselves various concepts which are learnt holistically, autentically, actively, and meaningfully. As stated by NCSS (1994: 163) that: "...Social studies teaching and learning are powerful when they are meaningful", thus the power of teaching and learning of social studies are meaningful for both teachers and students. The packaging way of learning experience which is designed by the teacher absolutely affect the meaningfulness of experience to the students as furhter stated by NCSS that:

The most effective teachers, however, do not diffuse their efforts by covering too many topics superficially. Instead, they select for emphasis the most useful landmark locations, the most representative case studies, the most inspiring models, the truly precedent-setting events, and the concepts and principles that their students must know and be able to apply in their lives outside of school.

Teaching learning process designed by the teachers should be able to support the students that what they have learn will eventually be applied to their real lives outside of school. Meaningful teaching-learning activity is focussed on the most important idea of what the students are learning. The teachers support the students to connect the ideas with their knowledge and with what they have experienced before.

Learning experience shows more on the connection of conceptual elements which make the learning process to be more effective. Conceptual connection which is learn conceptual relevant field study will form a scheme (concept), the students will thus gain the integrity and integrality of knowledge. The gaining of learning, integratedness, knowledge, and integrality view of real life and world can only be reflected from integrated learning.

\section{Theoretical Framework}

Education experts have made a lot of studies to develop various models of teaching social studies as an approach in the development of learning process in order to enhance students' critical and meaningful thinking skills. It is done because, in practice, social studies learning process is less supportive to the enhancement of critical and meaningful thinking skills.

Kemdikbud (2013) has stated that integtated learning is fundamentally a learning approach which enables thelearners, individually or collectively, to be active in searching, digging and finding concepts 
and principles holistically and autentically. Through integrated learning, the students are able to gain direct experience that can empower them to achieve, keep and produce impressions towards what they have learnt. Finally, the students are skillful in finding various concepts to learn.

Learning experience emphasizes to be more on conceptual elements tie to make teaching learning more effective. Conceptual tie which is learnt from relevant side of study will form a scheme (concept) so that the learners gain the integrity and integrality of knowledge. The gaining of learning integrity, knowledge and the integrality of view point about real life and world can only be reflected from integrated learning.

\section{Research Hypotheses}

Reciprocally with the research questions which have been proposed, the hypotheses of this research are:

1. Integrated social studies learning gives significant effect to the enhancement of students' critical thinking skill.

2. Integrated social studies learning gives significant effect to the enhancement of students' meaningful thinking skill.

3. Integrated social studies learning gives significant effect to the enhancement of students' critical and meaningful thinking skills.

\section{Research Methodology}

The research was conducted in SMP Negeri 4 Cianjur located at Jl. Adi Sucipta No. 2 Cianjur, Cianjur Regency - West Java. The population in this research were all $1^{\text {st }}$ semester students of SMP Negeri 4 Cianjur academic year 2013/2014, the total numbers were 835 persons with the sample were grade VII D and VII G. Grade VII D as an experimental class and grade VII G as a control group.

This research applied Nonequivalent Control Group Design. This design is the most commonly used in conducting educational research because the researcher used groups which had been determined. In this research, experimental group and control group were treated with different teaching and learning. Both of groups were given pretest and posttest, with similar test instruments, and then average scores were compared between experimental and control groups.

This research applied quasi experimental research method because, while conducting the research, it was impossible to examine all the free variables which affect bound variable due to the time and cost limit.

\section{The Operational Definition}

According to the title, thus the variables which were going to be examined were integrated approaches in Social studies learning, critical thinking and meaningful learning. In the following stages, operational definition elaborated was connected to the research variables being investigated.

1. Integrated Social studies Learning

Teaching - learning of Integrated Social studies is fundamentally a learning system which enables the students, individually and collectively, to be active in searching, digging, and finding concepts and principles holistically and authentically (Kemdikbud, 2013:126). In the learning of Integrated Social studies, learning program is arranged from various branches of science in social studies cluster. The enhancement of integrated learning, in this case, can take one 
topic from certain disciplinary, which are then completed, discussed, extended, and deepened with various science branches.

\section{Critical Thinking}

According to Ennis (1992), critical thinking is a process of thinking which happens to somebody which aims to make rational decisions about something he convinces its truth. Critical thinking skills are capabilities to resolve problems which result in trustable knowledge.

The indicators of critical thinking used in this research were indicator of critical thinkingskilldevelopedbyEnnis.Fromtwelve indicators, seven indicators were chosen: (1) to focus on questions; (2) to ask and answer questions about challenging explanation; (3) to define terms; (4) to make induction and to consider the deduction results; (5) to make and to consider decision values; (6) to observe and to consider observation finding; and (7) to determine an action.

\section{Meaningful Learning}

The foundation of meaningful learning as Ausubel and Robinson's view as stated (in Dahar, 2011: 95), the first process in meaningful learning was sorting (subsumption), in which new materials are related to the relevant thought and owned by somebody in his cognitive structure. Yani (2011) has stated that in the process of sorting or subsumption, the meaning can be accepted through the knowledge organization which students have previously owned in order to be related to his new knowledge. Therefore, learning is said to be meaningful if the students can acquire the meaningfulness logically from what they have learnt with thoughts existing in their cognitive structure.

The indicators of meaningful learning which were used in this research were meaningful indicators developed by Yani (2011) by referring to Ausubel: (1) to mention a number of concepts from the certain learnt theme; (2) to relate between two or more concepts from the theme learnt; and (3) to conclude a meaning about what have been learnt.

To obtain representative data, two instruments were applied, they were test and non-test type. The instrument of test type was questions about critical thinking skill, meaningful learning, and Integrated Social studies learning; while non-test instrument was observation and questionnaire sheets.

In this research, data were obtained from the result of pretest and pot-test, observation and questionnaire results about the learning process of Integrated Social studies. To obtain the data, the writer conducted pretest, post-test, observation and questionnaire diffusion. The data analysis was obtained by using Statistical Product and Service Solution (SPSS) program version 16 including normality test, homogeneity test, and research hypothesis test.

\section{The Result Findings And Discussion}

The entire research findings showed that the enhancement of critical and meaningful thinking skills in the experimental class is higher than the control class. The research finding showed that there was the difference between the gain of critical thinking between experimental class and control class. The gain of experimental class was 33.94 with the improvement about $44.5 \%$, while the gain of control class was 16.67 with the improvement about 22.6\%. The research findings to the meaningful learning were found that there was the difference in the gain of meaningful learning between experimental class and control class. The gain of experimental class 
was 31.62 with theimprovementabout $43.5 \%$, while the gain of control class was 11.16 with the improvement about $15.9 \%$. While the research of The effect of integrated social studies towards students' critical thinking and meaningful learning skills was obtained that the gain of experimental class was 29.35 with the improvement about $42.1 \%$, while the gain of control class was 15.23 with the improvement about $22 \%$.

\section{The Result of Observation and Questionnaires}

The average score from the observation of students' critical thinking skill was 3.0. Based on the above score range, the students' critical thinking skill was categorized good. The average score of the result of meaningful learning observation was 3.8. Based on the score range, the meaningfulness of Integrated Social studies learning process was categorized very good.

The result of questionnaires given to the student were found that almost all the students gave positive response to the Integrated Social studies learning. Likewise, the result of questionnaires given to the teachers, they gave positive response to the process of Integrated Social studies teachinglearning process.

\section{Discussion}

\section{The effect of Integrated Social studies Teaching and Learning towards Students' Meaningful Learning}

Based on the writer's experience, the teaching-learning process of Social studies in Junior High School is still carried out separately based on the study of Geography, Sociology, History, and Economics. The learning of Social studies separately conditioned the students to be more passive. Thestudents'thinking skillwasless developed optimally. This condition was triggered by the fact that the teaching-learning process was teacher oriented.

Ideally, during the process of teachinglearning, the teacher should be able to provide the students chances to develop their thinking skill. The need to develop students' critical thinking at school is admitted by a number of education experts. National Council for The Social Studies (1994:160) has stated that: "...Teacher should not only expose their students to curriculum content but should also provide them with opportunities to think and cummunicate in ways that will help students construct a working knowledge of such content"

This statement proposed by NCSS above showed that in the process of teachinglearning process, the teachers were required to be able to provide the students chances to think, which will help the students to build their own knowledge.

Teaching-learning of social studies fundamentally provides chances in optimizing thinking skills because one of the skills containing in Social studies learning according to Fraenkel (1980:9) is thinking skill, an ability to describe, define, classify, hypothesize, generalize, predict, compare, to contrast and to bear new ideas.

The research conducted by the writer about the learning implementation of Integrated Social studies can be concluded that Integrated Social studies learning significantly affect the enchancement of students' critical thinking skill. The critical thinking skills increased in control class, but averagely, experimental class's post-test scores were much higher than the control class's. 
This research strengthens the view that integrated learning is able to develop students' thinking skills because integrated learning is fundamentally a learning system which enables the learners individually and collectively, to be active in searching, digging, and finding concepts and principles holistically and authentically (Kemdikbud, 2013:126).

\section{The Effect of Integrated Social Studies Learning towards Students' Meaningful Learning}

Fromtheresearch conducted bythewriter about the implementation of integrated social studies learning social studies learning give significant effect to the meaningful learning. This meaningful learning is increased in control class, experimental class's post-test is much higher than the control class's.

In Junior High School (SMP), social studies shouldn't have been taught separately but integratedly. It is appropriate to the definition of social studies formulated by NCSS (1994: 3) which had defined that Social studies is "a integrated study from social and humanities sciences." The enhancement of integrated learning, in this case, can take one topic from a certain disciplinary which is then completed, discussed, expanded, and deepened with other disciplines. The topic/ the theme may be expanded from issues, events, and happening problems.

Ahmadi (2011: 2) has stated that integrated study using certain topics/themes as learning themes gives a lot of benefits for both the students and the teachers. The process of teaching-learning using theme will ease the students to focus on the learning theme and then the teaching-learning process will be more meaningful.

Ausubel, Novak, dan Hanesian (in Suparno, 1997: 54) have stated that meaningful learning is a learning process where new information is connected to the understanding structure owned by an individual who is learning. According to Ausubel, meaningful learning will be realized if the learner is able to relate the information he has just obtained to the relevant concepts (knownassubsumers) existinginthelearner's cognitive structure. However, if the learner is only trying to memorize the information he has just obtained without relating it to the relevant concepts in his cognitive structure; so, this condition is called rote learning.

Learning process is not only memorizing concepts or facts, but also an activity relating concepts to gain or to produce a-wholepackage understanding that the concept being learnt will be well-comprehended and uneasily forgotten. Therefore, to realize meaningful teaching-learning, the teachers should always try to find out and to dig up the concepts that the students have (or already know) and help them to integrate the concepts harmoniously with the new knowledge taught.

Throughintegratedlearning, thestudents are able to receive direct experience that they are able to enrich their power to receive, to keep and to produce impressions about what they have already learnt. Thus, the students are skillful to find out their various concepts that they have learnt.

\section{The Effect of Integrated Social studies Teaching and Learning towards the Enhancement of Students' Critical Thinking and Meaningful Learning Skills}

The practice of Social studies learning recently is generally carried out separately based on each subject such as Geography, History, Sociology, and Economics. This condition is worsened by the finding of 
teacher-centered class where teacher become the primary source of knowledge, thus lecture method become the main choice to determine teaching-learning strategy and this often ignores students' potency. Separated teaching-learning Social studies and teachers' strong domination tend to make the students passive. The students only achieve what their teachers convey without having any chances to develop their own thinking skills. And therefore, a learning approach is needed to empower students' thinking skill.

Social science is a science started from daily phenomena, and it cannot be separated from the dynamics of social improvement which constantly changes. The dynamics and the changes provide own peculiarity built upon where the society is. So, social studies learning for students should have related to the contexts that what the students received and enliven in both their cognition and their daily real life. This is appropriate to the main goal of social studies; it is to enhance students' potency in order to be susceptible towards social problems existing in the society, to be mentally positive to the restoration of existing imbalance, and to be skillful to overcome every daily problem faced by them and their society (Banks, 1977: 31).

The foal can be achieved if the subject programs of Social studies at school are well organized. The students are given freedom to enhance their thinking skills because, in order to be able to solve a problem, a highly skillful thinking analysis is needed, it is commonly known as critical thinking. The teachers are expected to present real life situation in the class and encourage the students to make the correlation between their own knowledge and the application in their life as a member of family and society.
Based on the hypothesis test result, it can be concluded that there is a significant effect of Integrated Social studies learning towards the students' critical and meaningful thinking skills. It shows, so that the implementation of teaching-learning integrated social studies give the students chance to learn actively, finding and constructing their own knowledge. Picking and choosing topic or theme taken from students' school environment real life enables the students to learn more meaningfully. This tends to empower the students with the expectation that the students are able to construct knowledge in their mind instead of memorizing the facts. In addition, the students may learn from experiencing not memorizing because knowledge is not a set of readily accepted facts or concepts, but it is something that must be constructed by the students themselves.

Thestudentswillearnmoremeaningfully by doing, finding, and constructing their new knowledgeandskillsthemselves. Thelearning process of Integrated Social studies enables the students to be skillful in finding their various concepts which are learnt holistically, autentically, actively and meaningfully, as stated by NCSS (1994: 163): "...Social studies teaching and learning are powerful when they are meaningful", thus, the power of Social studies is its meaningfulness to the students and the teachers.

\section{Conclusion}

Based on the result of data processing and analysis, it can be concluded that:

1. The Integrated Social studies teaching and learning significantly affect the enhancement of students' critical thinking skill. It can be seen from the difference of students' critical thinking 
skill in experimental class before and after the implementation of the Integrated Social studies teaching and learning. The students' critical thinking skill also increased in control class (separated Social studies teachinglearning), but the average post-test score of experimental class (Integrated Social studies teaching-learning) is much higher than the control class's. Therefore, the implementation of Integrated Social studies teaching and learning is capable of improving students' critical thinking skill higher than that of separated Social studies teaching and learning.

2. The Integrated Social studies teaching and learning significantly affect the enhancement of students' meaningful learning skill. It can be seen from the difference of students' meaningful learning skill in experimental class before and after the implementation of the Integrated Social studies teaching and learning. The students' meaningful learning skill also increased in control class (separated Social studies teachinglearning), but the average post-test score of experimental class (Integrated Social studies teaching-learning) is much higher than the control class's. Therefore, the implementation of integrated social studies teaching and learning is capable of improving students' meaningful learning skill higher than that of separated social studies teaching and learning.

3. The integrated social studies teaching and learning significantly affect the enhancement of students' critical thinking and meaningful learning skills. It can be seen from the difference of students' critical thinking and meaningful learning skills in experimental class before and after the implementation of the Integrated Social studies teaching and learning. The students' critical thinking and meaningfullearningskillsalsoincreased in control class (separated Social studies teaching-learning), but the average post-test score of experimental class (Integrated Social studies teaching-learning) is much higher than the control class's. Therefore, the implementation of Integrated Social studies teaching and learning is capable of improving students' critical thinking and meaningful learning skills higher than that of separated Social studies teaching and learning.

Shoving off the research findings, the writer gives the following suggestions and inputs:

1. The Integrated Social studies teaching and learning is able to enhance students' critical thinking and meaningful learning skills. Therefore, this Integrated Social studies can be implemented in the teaching and learning process by the teachers. To achieve optimal result, the teachers are recommended to learn it first in order to comprehend it conceptually and practically.

2. Social studies teachers are expected to continuously improve their competency in teaching and learning process, especially correlated to the implementation of Integrated Social studies by digging up various knowledge related to the teaching and learning in order to enhance students' critical thinking and meaningful 
learning skills. In this case, Social studies teachers are expected to actively communicate with other teacher to do some sharing about various existing problems because recently Social studies Education face some challenges to take part in enhancing students' skills and optimizing thinking potency and meaningful learning. The sharing result, especially about integrated social studies teaching and learning, is expected that in the end, the teachinglearning process of social studies can grow skills in problem solving, cooperating, and communicating which may train and stimulate the students to improve their critical reasoning power.

3. Teachers' creativity to prepare learning experience and teaching-learning theme is required in the Integrated Social studies teaching and learning process so that it becomes interesting, fun, integrated, and meaningful.

4. The students and the teacher have positive attitude to the implementation of Integrated Social studies teaching and learning. Therefore, Integrated Social studies teaching and learning may be applied by the teachers in learning process at class, with the expectation that the students' social studies learning achievement is getting better.

5. Social studies teachers must own competency in implementing Integrated Social studies teaching and learning and it cannot be delayed. Therefore, Education official or related institute may facilitate training to the Social studies teachers in order to be competent in Integrated Social studies teaching and learning.
6. Integrated Social studies teaching and learning may be used by other researchers as an input and may give chances develop this research more largely in the expected skill aspects and hopefully can describe the benefits of Integrated Social Science teaching and learning more largely.

\section{REFERENCES}

Abdulkarim, A. (2008). Model Keterampilan Berpikir dalam Pembelajaran IPS. Scientific Research Journal. 16, (30), 7-17.

Abrami, PC et al. (2008). Instructional Interventions Affecting Critical Thinking Skills and Dispositions: A Stage 1 Meta-Analysis. Concordia University, Montreal. Quebec. Canada [Online].Available on :http://rer. sagepub.com/content/78/4/1102. abstract[Februariy 20th , 2012]

Ahmadi, I.K. dan Amri, S. (2011). Mengembangkan Pembelajaran IPS Terpadu Analisis Kritis Tentang Metode, Strategi, Evaluasi, dan Media Pembelajaran Bidang Studi Sejarah, Geografi, Ekonomi, Sosiologi, Antropologi dan Isu Pembelajaran IPS Terpadu. Jakarta: Prestasi Pustaka.

Al-Muchtar, S. (2013). "Pengembangan Kemampuan Berpikir Tingkat Tinggi (Higher Order Thinking Skills) dalam Pembelajaran IPS" Papers on the Teachers Training of Citizenship Education, Geography in Excellent Senior High School on June 27th 2013. Ausubel, D.P. and Fitzgerald, D., (1961). Meaningful Learning and Retention: Intrapersonal Cognitive Variables. In Review of Educational Research. [Online], Vol 31, ( 5), page 500-510. Available on: http://www.jstor.org/ stable/1168901 [5 October 2013] 
Banks, J.A., (1977). Teaching Strategies for the Social Studies Inquiry, Valuing, and Decision-Making. Seattle. University of Washington: Addison Wesley Publishing Company.

Creswell, John W. (2009). Research Design. Qualitative, Quantitative, and Mixed Methods Approaches. Thousand Oaks California.

Dahar,R.W. (2011). Teori-Teori Belajar \& Pembelajaran. Jakarta:Erlangga

Depdiknas RI. (2006). Panduan Pengembangan Pembelajaran IPS Terpadu. Jakarta : Depdiknas.

Ennis, R.H. (1985). Goals for A Critical Thinking Curriculum. Developing Minds A Resource Book for Teaching Thinking. Virginia: Association for Supervisions and Curriculum Development (ASCD).

Ennis, R. (1992). Critical thinking: What is it? Proceedings of the Forty-Eighth Annual Meeting of the Philosophy of Education Society Denver. Colorado, March 27-30. [Online]. Available on :http://www.ed.uiuc.edu/PES/92_ docs/Ennis.HTM [15 September 2013]

Ennis. R.H. (1995). Critical Thinking. University of Illinois

Fisher, A. (2007). Berpikir Kritis Sebuah Pengantar. Jakarta:Erlangga

Fraenkel, J.R., (1980). Helping Students Think Value Strategies for Teaching Social Studies. New Jersey : PrenticeHall.

Jonassen, D. et al on. What is Meaningful Learning. Posted on March 28, 2011 by ivymariewallace [Online]. Available on:http:/ ivymariewallace.wordpress. com/2011/o3/28/jonassen-d-et-allon-what-is-meaningful-learning[14 Oktober 2013]
Kemdikbud RI. (2013). Modul Pelatihan Implementasi Kurikulum 2013 Ilmu Pengetahuan Sosial SMP. Jakarta: Kemdikbud

Koswara, D., (2011). Pembelajaran Kreatif dan Bermakna. [Online] Tersedia:http://file.upi.edu / Direktori/FPBS/Jur._Pend._Bahasa_ Daerah/195906141986011Dedi_ Koswara/Pembelajaran_Kreatif_Dan_ Bermakn1.Pdf [23 Juli 2013]

Kurniawan, D. (2011). Pembelajaran Terpadu Teori, Praktik dan Penilaian. Bandung:Pustaka Cendikia Utama National Council for the Social Studies. (1994). The Curriculum Standards for Social Studies. Washington DC: NCSS Rante, Susanna vonny noviana. (2008). Penerapan Model Pembelajaran Kooperatif Tipe Jigsaw pada Mata Pelajaran IPASD untukMeningkatkan Penguasaan Konsep dan Keterampilan Berpikir Kritis Siswa. Tesis pada SPS UPI Bandung:tidak diterbitkan.

Riduwan. (2010). Metode dan Teknik Menyusun Tesis. Bandung:Alfabeta.

Sagala, S. (2012). Konsep dan Makna Pembelajaran. Bandung: Alfabeta Sanjaya, Wina. (2008). Kurikulum dan Pembelajaran. Jakarta: Kencana

Sanjaya, Wina. (2011). Kurikulum dan pembelajaran Teori dan Praktik Pengembangan Kurikulum Tingkat Satuan Pendidikan (KTSP). Jakarta:Prenata Media Group.

Sapriya. (2012). Pendidikan IPS Konsep dan Pembelajaran. Bandung:Remaja Rosda Karya

Somantri, N. (2001). Menggagas Pembaharuan Pendidikan IPS. Bandung: Remaja Rosdakarya. 
YUYUN KURNIASARI,

The Effect of Integrated Social Studies Learning Towards the Enhancement of Student' Critical and Meaningfull Thinking Skills.

Sugiyono. (2009). Metode Penelitian Yani, Ahmad. (2010). Pengembangan Pendidikan Pendekatan Model Meaningful Learning Untuk Kuantitatif, Kualitatif daan R\&D. Meningkatkan Daya Nalar Siswa Bandung:Alfabeta

Suparno,P.(1997).Filsafat Kontruktivisme Melalui Aplikasi Mind Map Pada dalam Pendidikan. Yogyakarta: Kanisius. Mata Pelajaran Geografi di SMA. Dissertation in SPS UPI Bandung: unpublished.

Tilaar, H.A.R., Paat, J.P., dan Paat, L. (2011). Pedagogik Kritis Perkembangan, Zevin, Jack. (2007). Social Studies for Substansi, dan Perkembangannya di the Twenty-First Century: Methods Indonesia. Jakarta: Rineka Cipta

Wiriaatmadja, R. (2002). Pendidikan Sejarah di Indonesia: Perspektif and Materials for Teaching in Middle and Secondary Schools. New York: Routledge

Lokal, Nasional, dan Global. Bandung:

Historia Utama Press 